\title{
Aortic root surgery for young patients: The elephant in the room
}

\author{
John R. Doty, MD
}

\author{
From the Division of Cardiovascular and Thoracic Surgery, Intermountain Heart Institute, Murray, Utah. \\ Disclosures: Author has nothing to disclose with regard to commercial support. \\ Received for publication Aug 16, 2016; accepted for publication Aug 19, 2016 \\ Address for reprints: John R. Doty, MD, Division of Cardiovascular and Thoracic Surgery, Intermountain Heart \\ Institute, Eccles Outpatient Center, Suite 600, Intermountain Medical Center, 5169 S Cottonwood St, Murray, \\ UT 84107 (E-mail: john.doty@imail.org). \\ J Thorac Cardiovasc Surg 2016;152:1621 \\ $0022-5223 / \$ 36.00$ \\ Copyright (C) 2016 by The American Association for Thoracic Surgery \\ http://dx.doi.org/10.1016/j.jtcvs.2016.08.031
}

In my group's previous report of minocycline pigmentation of the aortic valve and ascending aorta, the patient was submitted for surgery because of aortic stenosis and underwent aortic valve replacement with a bovine prosthesis. ${ }^{1}$ The valvular disease in our older patient was due to calcific leaflet disease, and the unusual pigmentation was not the primary cause of valve degeneration.

The new report in this issue of the Journal by Cohen and colleagues $^{2}$ of unexpected rare pigmentation of the aortic valve as a result of long-term minocycline therapy is notable for two reasons. First, unlike the older patient with aortic insufficiency and ascending aortic aneurysm in an additional similar previous report, ${ }^{3}$ this patient was potentially a candidate for valve-sparing root replacement, because there was isolated aortic enlargement and only mild aortic insufficiency. A valve-sparing operation would have been ideal for this young patient because of his risk for both anticoagulation with a mechanical prosthesis and early degeneration of a tissue prosthesis.

Second, the patient is immunosuppressed after liver transplantation and is receiving long-term minocycline therapy for acne; alteration of his long-term medical regimen is unlikely. Although the pigmentation had not affected valve function to any major degree, the possibility of eventual valve degeneration remains unknown. It is doubtful that long-term immunosuppression will prevent prosthetic valve deterioration. More importantly, the patient will remain at increased risk for infective endocarditis because of the immunosuppression. regimen.

\section{References} 2014;19:339-40. 152:1618-9. $2009 ; 88: 1704$.

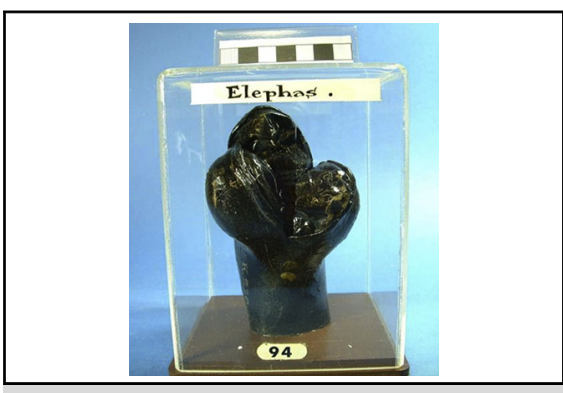

Aortic root of elephant, Hunterian Museum collection, Royal College of Surgeons, London.

\section{Central Message}

Long-term strategies for aortic root reconstruction in young patients include valve-sparing root replacement, bioprostheses, and mechanical prostheses.

See Article page 1618 .

The complex interactions among immunosuppression, minocycline, and a bioprosthetic heart valve are currently unknown. On balance, however, the decision to replace the aortic root with a tissue prosthesis seems to be the most prudent option. This operation provided the patient with the most predictable long-term result and avoided adding long-term anticoagulant therapy to his medical

1. Tsunekawa T, Jones KW, Doty JR. Black pigmented aortic valve and sinus of Valsalva caused by life-long minocycline therapy. Interact Cardiovasc Thorac Surg.

2. Cohen MA, Owens SR, Yang B. Minocycline pigmentation of the cardiac valves and aorta in a 29-year survivor of liver transplant. J Thorac Cardiovasc Surg. 2016;

3. Belcher E, Soni M, Azeem F, Sheppard MN, Petrou M. Minocycline-induced pigmentation of the aortic valve and sinuses of Valsalva. Ann Thorac Surg. 